\title{
Paleoenvironmental Interpretation of Last Millennium Sediments in the Marriaga Swamp, Atrato Delta, Colombia*
}

\author{
Liliana Betancurth Montes ${ }^{\mathrm{a}}$ - Julio Eduardo Cañón Barrigab
}

\begin{abstract}
This paper presents the first paleoenvironmental reconstruction of the last 1,130 a of the Marriaga Swamp in the Atrato River delta in northwestern Colombia. The geochemical analyses of a $220 \mathrm{~cm}$ sediment core retrieved from the swamp reveal interesting climatic episodes and sedimentary changes in the last millennium. We split the core into three segments, according to sediment features, organic carbon content (OC), and geological ages. Records show different alternations of humid and dry periods, biological productivity, carbonate precipitation, weathering grade, and high heavy metal concentrations. The segments also concur with the geochemical differences determined by $(\mathrm{Zr}+\mathrm{Rb}) / \mathrm{Sr}, \mathrm{Ca} / \mathrm{Ti} \mathrm{Mn} / \mathrm{Fe}, \mathrm{OC} / \mathrm{Ti}, \mathrm{Mg} / \mathrm{Ca} \mathrm{Ba} / \mathrm{Al}$, Sr/Al, and $\mathrm{Ca} / \mathrm{Al}$ ratios. The older sequence (between $1,130 \pm 90$ a and $870 \pm 70$ a) shows a dry period with intermittent flooding events and high OC production in subareal conditions, followed by a more humid environment between $870 \pm 70$ a and 530 $\pm 40 \mathrm{a}$, with depletion of trace element ratios and OC. The more recent period (530 $\pm 40 \mathrm{a}$ to present) evinces an environment dominated by the fluvial regime, based on a lower Ca/Al ratio and a rise of OC. The statistical correlations display three main clusters that distinguish among organic-biological productivity, bedrock source components, and heavy metal inputs.
\end{abstract}

Keywords: Swamp sediments; environmental reconstruction; trace elements; paleoclimate; weathering

Received: 31/07/2020 Accepted: 19/01/2021 Online: 23/07/2021

How to cite: L. Betancurth Montes and J. E. Cañón Barriga, "Paleoenvironmental Interpretation of Last Millennium Sediments in the Marriaga Swamp, Atrato Delta, Colombia", Cien.Ing.Neogranadina, vol. 31, no. 1, pp. 9-24, Jul. 2021.

* Research article

a PhD, MSc, Spc. in Environmental Engineering. BSc in Geology. Grupo de Modelación y Gestión Ambiental (gaia), Universidad de Antioquia, Medellín, Colombia. E-mail: gloria.betancurth@udea.edu.co ORCID: http:// orcid.org/0000-0002-4095-2722

b PhD and MSc in Hidrology. BSc in Civil Engineering. Grupo de Modelación y Gestión Ambiental (gaia), Universidad de Antioquia, Medellín, Colombia. E-mail: julio.canon@udea.edu.co ORCID: https://orcid. org/0000-0001-8041-2774 


\section{Interpretación paleoambiental de los sedimentos del último milenio en la Ciénaga de Marriaga, Delta de Atrato, Colombia}

Resumen: en este estudio se presenta la primera reconstrucción paleoambiental de los últimos 1130 años de la Ciénaga de Marriaga en el delta del río Atrato, en el noroeste de Colombia. Los análisis geoquímicos de un núcleo de sedimento de $220 \mathrm{~cm}$ recuperado en la ciénaga revelan episodios climáticos interesantes y cambios sedimentarios en el último milenio. Se dividió el núcleo en tres segmentos, según las características de los sedimentos, el contenido de carbono orgánico (CO) y las edades geológicas. Los registros muestran diferentes alternancias de períodos húmedos y secos, la productividad biológica, precipitación de carbonato, grado de meteorización y altas concentraciones de metales pesados. Los segmentos también coinciden con las diferencias geoquímicas determinadas por las relaciones (ZR+RB)/Sr, Ca/Ti Mn/Fe, CO/Ti, Mg/Ca Ba/Al, Sr/Al Ca/Al. La secuencia inferior (entre $1130 \pm 90$ a y $870 \pm 70$ a) muestra un período seco con inundaciones intermitentes y una alta producción de $\mathrm{CO}$ en condiciones subaéreas, seguida de un entorno más húmedo entre $870 \pm 70$ años y $530 \pm 40$ años, con agotamiento de las proporciones de oligoelementos y CO. El período más reciente (530 \pm 40 a al presente) evidencia un ambiente dominado por el régimen fluvial, basado en una relación Ca/AI más baja y un aumento de CO. Las correlaciones estadísticas muestran tres grupos principales que distinguen entre la productividad biológica orgánica, los componentes de la roca madre y los aportes de metales pesados.

Palabras clave: sedimentos de ciénagas, reconstrucción ambiental, oligoelementos, paleoclima, meteorización. 


\section{Introduction}

Lacustrine sediments are formed by accumulated organic and inorganic particles derived from different bedrock sources usually transported by rivers under continuous and episodic sediment loads [1]-[2]. Each lacustrine setting provides a unique record of the geographic, climatic, and geological variations occurring over time in a basin [3]-[7]. Proxies such as grain size, mineralogy, isotopes, organic matter, dating, and geochemistry provide valuable information to reconstruct the environmental record of such lacustrine environments [8]-[9]. This environmental record includes the analysis of sediment bedrock sources, mineral phases, sediment accumulation rates, weathering intensity, heavy metal thresholds, and chemical processes to identify past environmental disturbances [10]-[12].

The climate of the last millennium has been widely investigated worldwide. However, some tropical lacustrine settings remain unexplored. That is the case of swamps in the Atrato River delta in Colombia, in which paleoenvironmental reconstructions are limited to characterizations based on water, surface sediments, or shallow cores $(<$ $80 \mathrm{~cm}$ ) [13]-[15]. This study focuses on the flood plain area of the Atrato River, considered one of the most important rivers of western Colombia, with more than 20 lacustrine systems spread along its vast flood plain [13]. The Marriaga Swamp is the northernmost lacustrine landform of the Atrato River delta ( $8^{\circ} 06^{\prime} 70^{\prime \prime} \mathrm{N}$; 76 $78^{\circ}$ 28” W; 15 m.a.s.l.) with a surface area of $12.47 \mathrm{~km}^{2}$ and a maximum water depth (measured during this research) of 4 $\mathrm{m}$ (Fig. 1). The swamp is connected to two main streamflows: the Atrato River to the west and the Caño Tarena to the north. The area has a tropical climate corresponding to the Intertropical Convergence Zone (ITCZ) with average annual rainfall from 2,500 to 3,000 $\mathrm{mm}$ [16]-[17]. The average temperature is estimated at $33.8{ }^{\circ} \mathrm{C}$. Humidity ranges from 80 to $86 \%$ throughout the year [18].

The principal human activity in the area is fishing by the citizens of a small village named Marriaga. This village is located on the east side of the swamp, along the inlet feeds from Atrato River, just in the main entrance towards the swamp.

Bedrock in the area consists of Cretaceous rocks of igneous origin (basalts, andesites, and granitoids) cropping to the west and south of the Marriaga Swamp in the Baudó-Darien mountain ridge [19]-[20]. A broad group of Eocene sedimentary rocks outcrop towards the west of the Marriaga Swamp and comprise cherts, detrital limestones, mudstones, carbonaceous sandstones, and marls [21]. The Quaternary deposits of the vast alluvial plain are composed of clay and silt sediments [22] surrounding the Marriaga Swamp.

This research aims to determine the depositional processes and climatic impacts of the Marriaga Swamp, northern Colombia, in the last millennium, using quantitative data obtained from XRF geochemical analyses. It is the first approach to understanding the Marriaga Swamp's paleoenvironmental features with major and trace elements interpretations within the framework of the Atrato delta. 

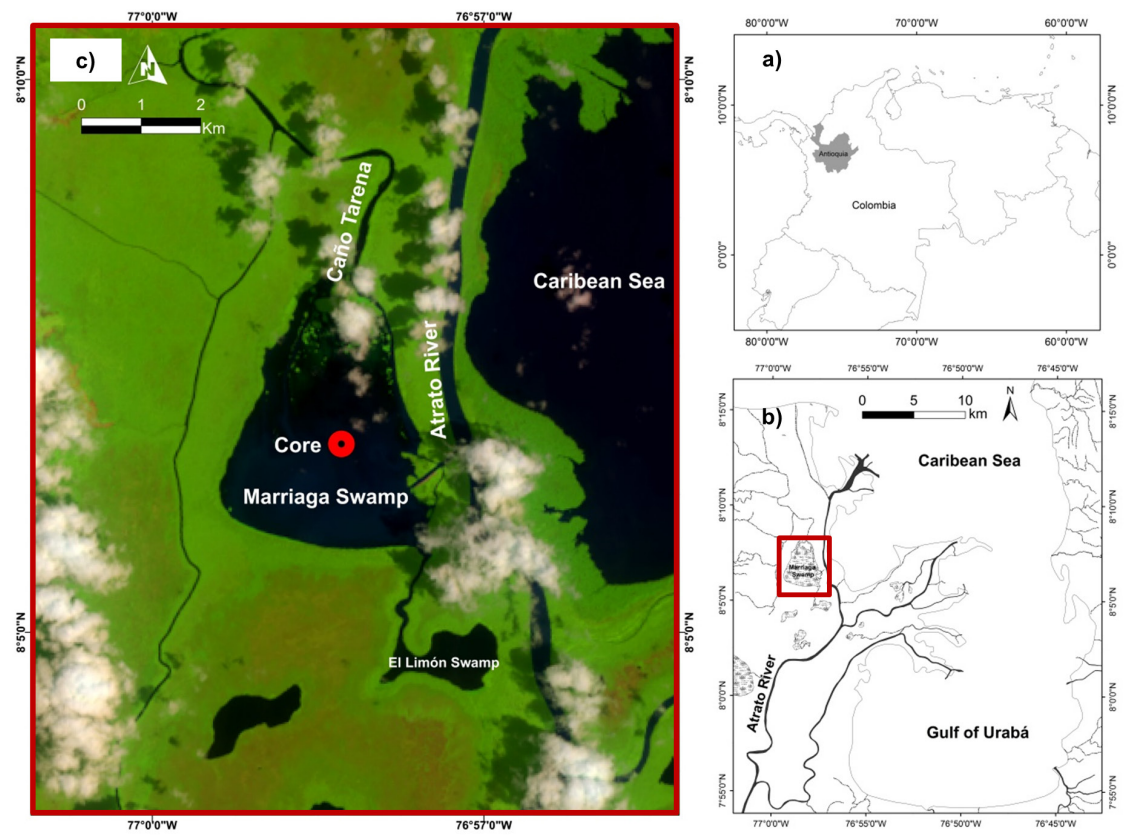

Fig. 1. Location of the Marriaga Swamp. (a) Regional location and (b) detailed location.

Source: Modified from IGAC Topographic Base (2015) and Landsat image EOS (2020).

\section{Materials and Methods}

We drilled a sediment core at the center of the Marriaga Swamp with a Livingstone Bolivia corer. The core consists of two overlapping sections with a total length of $220 \mathrm{~cm}$, retrieved at the central area of the swamp where the depth of water to surface sediments was $4 \mathrm{~m}$. We sliced the core into 16 sections, between 5 and $10 \mathrm{~cm}$ long each, according to visually identified stratigraphic changes. We chose eight samples distributed on top, middle, and bottom sections of the sequence for detailed characterizations.

The physical properties of the sediment layers were initially determined with visual and tactile inspections of color, texture, and organic matter content. The geochemical analyses followed the patterns related to the three segments previously defined by their sediment characteristics, age, and organic carbon (OC) content. We measured variations of major and trace elements and determined correlations from which we analyze dry and humid periods, biological productivity, carbonate precipitation, fluvial-marine sediment input fluctuations, and human impacts.

We performed the geochemical analyses at the Universidad de Antioquia Spectrometry Laboratory, using an ARL OPTIM'X WDRRF
Spectrometer/Thermo Scientific. The procedure consisted of grounding samples in an S-1000 RETCH Centrifugal Ball Mill with a zirconium oxide vessel at 3,000 rpm for 5 minutes. The grounded powder was calcinated at $550{ }^{\circ} \mathrm{C}$ for three hours to determine Loss of Ignition (LOI) and calculate OC. The geochemical data included concentrations of ten oxides $\left(\mathrm{SiO}_{2}, \mathrm{Al}_{2} \mathrm{O}_{3}, \mathrm{Fe}_{2} \mathrm{O}_{3}\right.$, $\mathrm{MgO}, \mathrm{Na}_{2} \mathrm{O}, \mathrm{CaO}, \mathrm{K}_{2} \mathrm{O}, \mathrm{TiO}_{2}, \mathrm{P}_{2} \mathrm{O}_{5}$, and $\mathrm{MnO}$ ) and 22 trace elements $(\mathrm{Cl}, \mathrm{S}, \mathrm{Ba}, \mathrm{V}, \mathrm{Cu}, \mathrm{Zr}, \mathrm{Sm}, \mathrm{Cr}, \mathrm{Zn}$, $\mathrm{Sr}, \mathrm{W}, \mathrm{Tb}, \mathrm{Ni}, \mathrm{Co}, \mathrm{La}, \mathrm{Rb}, \mathrm{Br}, \mathrm{Y}, \mathrm{Sc}, \mathrm{Ga}$, and Cd). Measurements were made with the standard and duplicate samples (Table 1).

The ages at the top, middle, and bottom sections were determined with the Infrared Stimulated Luminescence (IRSL) technique in the Institute of Earth and Environmental Sciences laboratory at the Albert-Ludwigs-University of Freiburg, Germany [23]. The basic sample was prepared in the Universidad EAFIT photoluminescence laboratory in Medellín, Colombia. The core was split into two parts, selecting three samples on the top, middle, and bottom of the sedimentary sequence. A first dry process was carried out at $40^{\circ} \mathrm{C}$ for 24 hours to obtain the water content. The robust material was prepared at the University of Freiburg red-light adapted laboratory. Before an $\mathrm{HCl}(30 \%)$ and $\mathrm{H}_{2} \mathrm{O}^{2}$ 
(30\%) treatment, several sieve stages were com- Both coarse and fine fractions were used for age pleted to remove carbonates and organic matter. determination procedures.

Table 1. Major (wt \%) and trace (ppm) elements composition in the Marriaga Swamp

\begin{tabular}{|c|c|c|c|c|c|c|c|c|}
\hline Samples & S1 & S2 & S3 & S4 & S5 & S6 & 57 & 58 \\
\hline LOI & 17,83 & 16,33 & 15,20 & 14,38 & 13,49 & 21,22 & 21,61 & 19,35 \\
\hline$O C$ & 10,34 & 9,47 & 8,82 & 8,34 & 7,82 & 12,31 & 12,54 & 11,22 \\
\hline Depth & 5,00 & 33,00 & 61,00 & 82,00 & 113,00 & 162,00 & 201,00 & 219,00 \\
\hline $\mathrm{SiO}_{2}$ & 41,62 & 41,16 & 45,68 & 45,25 & 46,41 & 44,27 & 46,79 & 52,39 \\
\hline $\mathrm{Al}_{2} \mathrm{O}_{3}$ & 20,37 & 17,89 & 17,83 & 18,13 & 18,64 & 19,06 & 19,16 & 19,41 \\
\hline $\mathrm{Fe}_{2} \mathrm{O}_{3}$ & 11,52 & 11,27 & 10,56 & 10,53 & 10,50 & 9,14 & 8,88 & 8,38 \\
\hline $\mathrm{MgO}$ & 3,38 & 2,86 & 3,31 & 3,44 & 3,37 & 3,58 & 3,94 & 4,04 \\
\hline $\mathrm{Na}_{2} \mathrm{O}$ & 0,94 & 1,16 & 1,39 & 1,50 & 1,31 & 2,08 & 2,43 & 2,50 \\
\hline $\mathrm{CaO}$ & 1,43 & 1,48 & 1,75 & 1,77 & 1,71 & 1,71 & 2,57 & 2,76 \\
\hline $\mathrm{K}_{2} \mathrm{O}$ & 0,90 & 0,98 & 1,25 & 1,33 & 1,32 & 1,40 & 1,37 & 1,51 \\
\hline $\mathrm{TiO}_{2}$ & 0,65 & 0,67 & 0,76 & 0,78 & 0,76 & 0,78 & 0,79 & 0,74 \\
\hline $\mathrm{P}_{2} \mathrm{O}_{5}$ & 0,32 & 0,19 & 0,09 & 0,17 & 0,10 & 0,27 & 0,26 & 0,15 \\
\hline $\mathrm{MnO}$ & 0,40 & 0,19 & 0,11 & 0,10 & 0,11 & 0,09 & 0,12 & 0,11 \\
\hline $\mathrm{Cl}$ & 606 & 3320 & 3950 & 4140 & 2490 & 6880 & 7260 & 4550 \\
\hline $\mathrm{S}$ & 2630 & 3840 & 13100 & 18900 & 17000 & 6370 & 2610 & 976 \\
\hline $\mathrm{Ba}$ & 589 & 429 & 497 & 514 & 502 & 810 & 937 & 977 \\
\hline V & 270 & 214 & 206 & 210 & 205 & 253 & 215 & 217 \\
\hline $\mathrm{Cu}$ & 273 & 261 & 269 & 246 & 254 & 253 & 220 & 207 \\
\hline $\mathrm{Zr}$ & 123 & 165 & 233 & 197 & 177 & 304 & 380 & 456 \\
\hline Sm & 146 & 175 & 150 & 152 & 199 & 170 & 121 & 0 \\
\hline $\mathrm{Cr}$ & 104 & 138 & 180 & 179 & 194 & 174 & 187 & 166 \\
\hline $\mathrm{Zn}$ & 148 & 134 & 144 & 138 & 142 & 157 & 126 & 122 \\
\hline $\mathrm{Sr}$ & 111 & 159 & 202 & 200 & 192 & 201 & 260 & 274 \\
\hline W & 108 & 103 & 112 & 105 & 90 & 61 & 0 & 74 \\
\hline $\mathrm{Tb}$ & 129 & 121 & 123 & 107 & 153 & 122 & 111 & 94 \\
\hline $\mathrm{Ni}$ & 111 & 89 & 100 & 111 & 115 & 120 & 113 & 112 \\
\hline $\mathrm{Ar}$ & 178 & 186 & 146 & 0 & 111 & 149 & 0 & 0 \\
\hline Co & 65 & 71 & 81 & 80 & 72 & 78 & 61 & 38 \\
\hline La & ND & ND & ND & ND & ND & ND & ND & 65 \\
\hline $\mathrm{Rb}$ & 27 & 36 & 38 & 44 & 35 & 51 & 37 & 40 \\
\hline $\mathrm{Br}$ & 22 & 48 & 42 & 29 & 26 & 39 & 23 & 14 \\
\hline$Y$ & 22 & 24 & 27 & 25 & 25 & 26 & 28 & 16 \\
\hline Sc & 22 & 20 & 26 & 0 & 21 & 0 & 0 & 29 \\
\hline $\mathrm{Ga}$ & 11 & 20 & 13 & 16 & 17 & 26 & 20 & 18 \\
\hline $\mathrm{Cd}$ & ND & ND & ND & ND & ND & ND & ND & 65 \\
\hline
\end{tabular}

Note. ND: Not detected.

Source: Own elaboration.

Paleoenvironmental Interpretation of Last Millennium Sediments in the Marriaga Swamp, Atrato Delta, Colombia 


\section{Results and Discussion}

\section{Physical Features of Sediments}

The $220 \mathrm{~cm}$ sedimentary sequence consists of laminated grayish to brownish fine sand, silt, and clay layers, intercalated with peat layers (Fig. 2). The ages estimated with the IRSL technique indicate $1,130 \pm 90$ a at the bottom of the core, around 870 $\pm 70 \mathrm{a}$ in the middle section, and around $530 \pm$ 40 a on the top. The core was divided into three segments, according to sediment features and estimated ages: bottom segment (Seg. i: 220-135 $\mathrm{cm} ; 1,130 \pm 90$ to $870 \pm 70$ a), middle segment (Seg. ii: $135 \mathrm{~cm}-70 \mathrm{~cm} ; 870 \pm 70$ to $530 \pm 40 \mathrm{a}$ ), and upper segment (Seg. iii: $70-0 \mathrm{~cm} ; 530 \pm$ recent a).

Seg. i involves the coarser sediments of brownish fine sand to silty sediments, interbedded with black laminations enriched with organic matter and mica. Seg. ii comprises grey-brown alternations of silt and clay sediments with thin sandy laminations, scarce organic matter, and mica content. Seg. iii comprises greyish silt with intercalations of clay with poor content of organic matter.

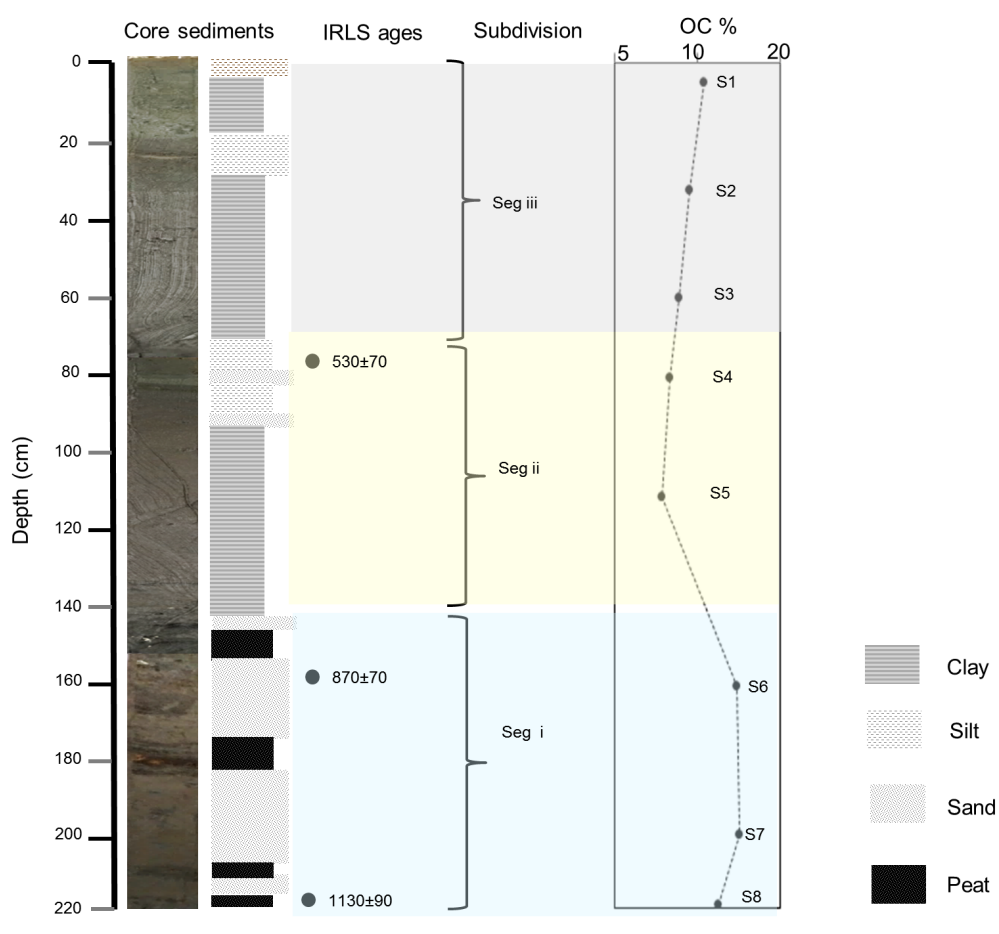

Fig. 2. Photograph of the core and schematic sedimentary column of Marriaga Swamp sediments. Ages obtained by IRSL. Segment division is represented by color transparency. Organic carbon content.

Source: Own elaboration

Organic matter content is present in the core, with values ranging between 7.8 and $12.5 \%$. In the oldest segment (Seg. i), the organic matter content is considerably high, as evinced by four peaty layers. These layers indicate exposure conditions that allowed vegetation cropping between approx. $1,130 \pm 90$ and $870 \pm 70$ a. In Seg. ii (between $870 \pm 70$ and $530 \pm 40$ a), the organic matter is low and relates to a sedimentary sequence of clay that indicates subaerial and redox conditions. The coarser sediments in the most recent segment (Seg. iii) indicate the influence of high-energy flows feeding the swamp. Seg. iii is characterized by an increase in organic matter content towards the surface, approx. $530 \pm 40$ a to present. However, Seg. iii resembles Seg. ii in terms of grain size and the absence of clear peaty layers, except for millimetric laminations. 


\section{Geochemistry}

\section{Major elements}

$\mathrm{Si}, \mathrm{Al}, \mathrm{Fe}, \mathrm{Mg}, \mathrm{Na}, \mathrm{Ca}$, and $\mathrm{K}$ are associated with a siliciclastic provenance (Fig. 3). Seg. i (lower part of the sequence) has high $\mathrm{Si}, \mathrm{Mg}, \mathrm{Na}, \mathrm{Ca}$, and $\mathrm{K}$ concentrations, whereas Seg. ii (middle of the sequence) shows an increment of $\mathrm{Fe}$ and a reduction of $\mathrm{Mg}$ and $\mathrm{Na}$. Seg. iii (upper sequence) exhibits high $\mathrm{Al}$ and $\mathrm{Mg}$ concentrations and reductions in $\mathrm{Si}$ and $\mathrm{Ca}$. The patterns of $\mathrm{Ca}$ and $\mathrm{Mg}$ are more complex, probably due to the variety of bedrock sources with detrital and endogenic inputs.

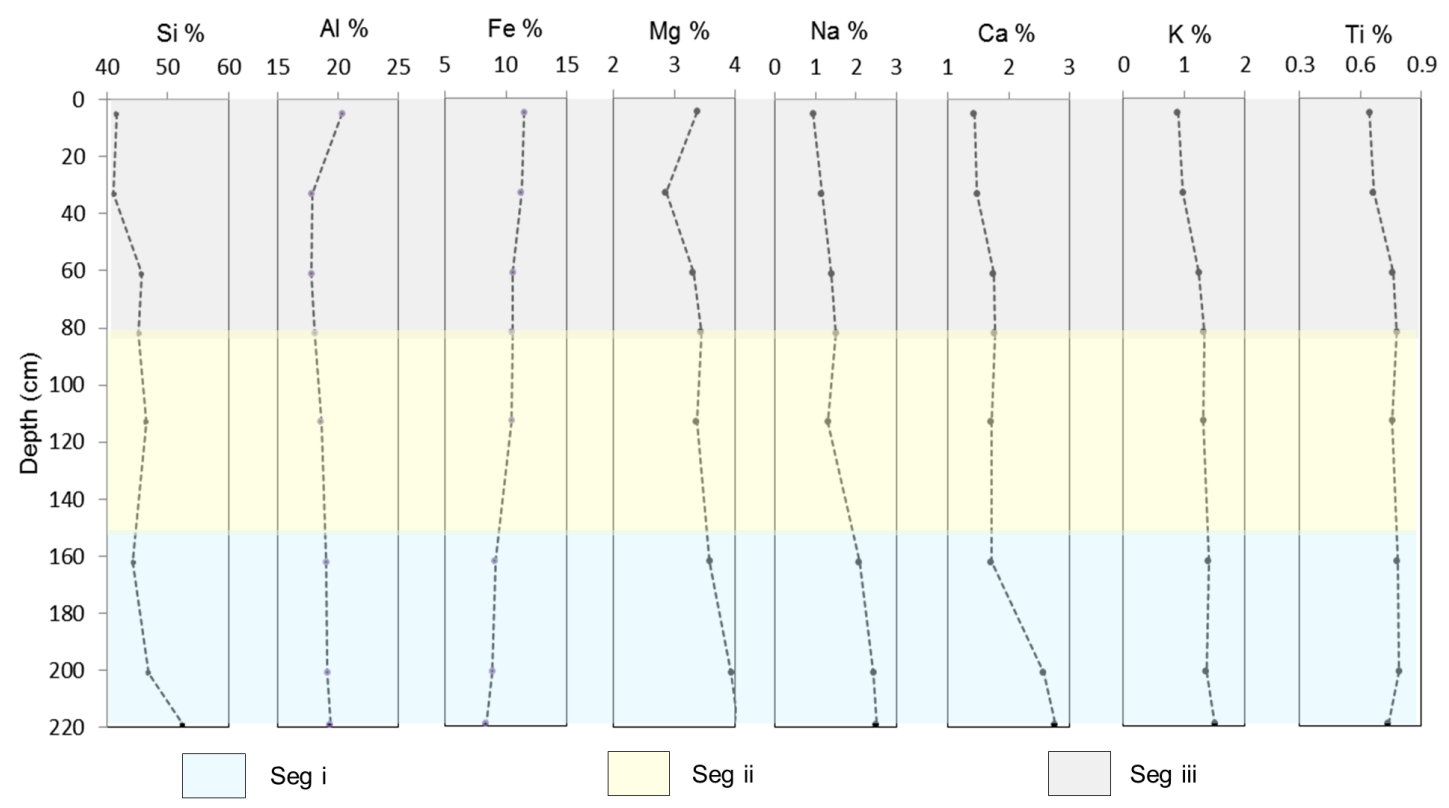

Fig. 3. Major element concentrations along the Marriaga Swamp sedimentary sequence.

Source: Own elaboration

High concentrations of major elements ( $\mathrm{Si}, \mathrm{Al}$, $\mathrm{K}, \mathrm{Ti}$, and $\mathrm{Fe}$ ) represent detrital contributions related to flooding events; high values of Ca demonstrate sediment reworking during dry periods or swamp level fluctuations [24], whereas $\mathrm{Mg}, \mathrm{Cl}$, and $\mathrm{Na}$ indicate salinity intrusions [25]-[26].

\section{Trace elements}

The extended analysis of trace elements exposes several paleoenvironmental features. Dry and humid periods, for instance, are related with $(\mathrm{Zr}+\mathrm{Rb}) /$ $\mathrm{Sr}$ and $\mathrm{Ca} / \mathrm{Ti}$ ratios; biological productivity is represented by $\mathrm{Mn} / \mathrm{Fe}, \mathrm{OC} / \mathrm{Ti}$, and $\mathrm{Mg} / \mathrm{Ca}$ ratios (Fig. 4). Carbonate precipitation employs $\mathrm{Ba} / \mathrm{Al}, \mathrm{Sr} / \mathrm{Al}$, and $\mathrm{Ca} / \mathrm{Al}$ ratios (Fig. 5), and the possible anthropogenic impact is associated with $\mathrm{Cu}, \mathrm{Ni}, \mathrm{Zn}, \mathrm{Co}$, and $\mathrm{Cr}$ (Fig. 6).
The $(\mathrm{Zr}+\mathrm{Rb}) / \mathrm{Sr}$ ratio reveals terrigenous inputs, whereas the $\mathrm{Ca} / \mathrm{Ti}$ ratio indicates carbonate production [26] and the relation with drought in humid conditions. High $(\mathrm{Zr}+\mathrm{Rb}) / \mathrm{Sr}$ and $\mathrm{Ca} / \mathrm{Ti}$ imply possible drought conditions observed in Seg. i (220 to $160 \mathrm{~cm}$ ) from $1,130 \pm 90$ and $870 \pm 70$ a, with a significant fall towards more recent sediments. A relatively constant humid environment is consistent with these low ratios observed in the upper $120 \mathrm{~cm}$ of the core (Seg. ii and Seg. iii).

Biological productivity was important from $1,130 \pm 90$ to $870 \pm 70$ a. The middle to low $\mathrm{Mn} / \mathrm{Fe}$ ratio in Seg. i indicates some intermittent, short periods of paleo-redox conditions $(220-160 \mathrm{~cm})$. Low values of $\mathrm{Mn} / \mathrm{Fe}$ at 120 to $60 \mathrm{~cm}$ in Seg. ii indicate more oxygenated conditions from $870 \pm 70$ to $530 \pm 40$ a. The rise of biological productivity 
remains from $60 \mathrm{~cm}$ to the surface. Important $\mathrm{OC} / \mathrm{Ti}$ ratios show high concentrations in Seg. $\mathrm{i}$ and Seg. iii with a significant decrease at Seg. ii. The $\mathrm{Mg} / \mathrm{Ca}$ is relatively high at Seg. iii, close to the surface. The fine lamination of sediments preserved in upper and lower sediments indicates anoxic conditions in the Marriaga Swamp in Seg. i and Seg. iii

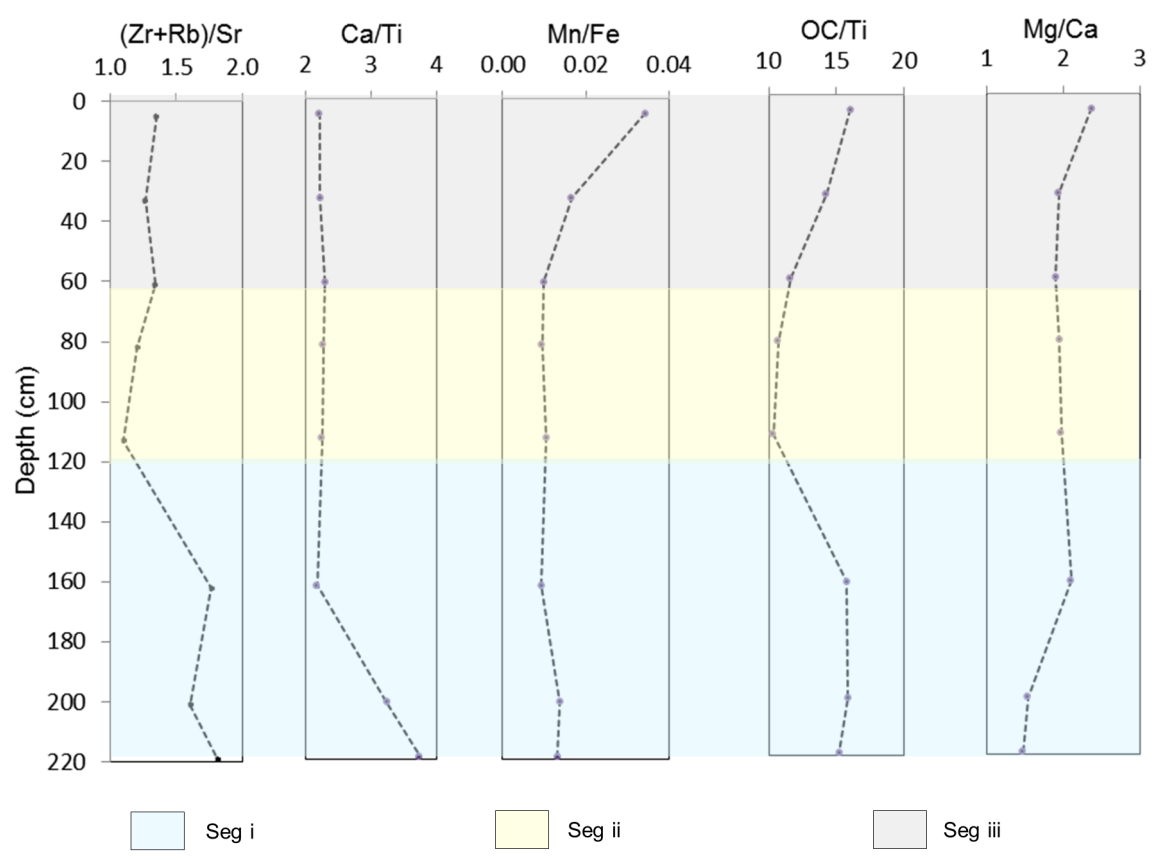

Fig. 4. Trace element plots for dry, humid, and biological productivity interpretations.

Source: Own elaboration

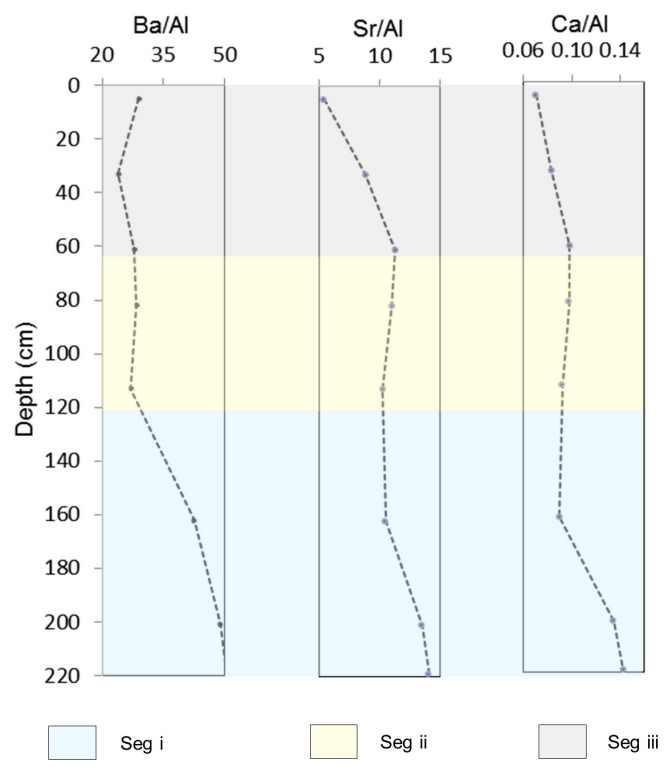

Fig. 5. Trace element plots to interpret carbonate precipitation.

Source: Own elaboration 


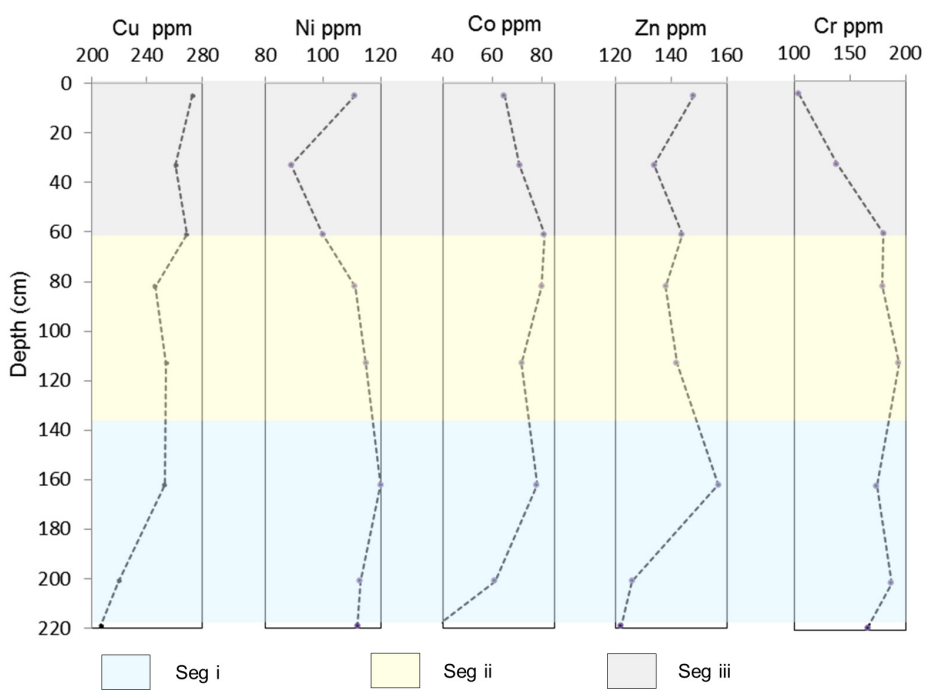

Fig. 6. Heavy metal plot to interpret natural source and human impact for $\mathrm{Cu}, \mathrm{Ni}, \mathrm{Zn}, \mathrm{Co}$, and $\mathrm{Cr}$. Source: Own elaboration

Carbonate precipitation (Fig. 5.), interpreted from $\mathrm{Ba} / \mathrm{Al}, \mathrm{Sr} / \mathrm{Al}$, and $\mathrm{Ca} / \mathrm{Al}$ ratios, shows high $\mathrm{Ba} / \mathrm{Al}$ profile values in Seg. i $(220-120 \mathrm{~cm})$, with a notable increase in the sequence's upper sediments, suggest authigenic processes. The presence of ion-rich waters and chemical precipitation is interpreted from $\mathrm{Sr} / \mathrm{Al}$ and may indicate a saline, brackish stage in the Marriaga Swamp from 1,130 \pm 90 to $530 \pm 40$ a $(220-60 \mathrm{~cm})$, with clear decreasing values from $60 \mathrm{~cm}$ to surface.

The brackish state is consistent with the fact that the Marriaga Swamp could be affected by seawater inputs during high tidal conditions. High values of $\mathrm{Ca} / \mathrm{Al}$ in the lower sequence $(220-60 \mathrm{~cm})$ correspond to half of Seg. i. Moderate and constant values from 160 to $60 \mathrm{~cm}$ are compatible with half of Seg. i and whole Seg. ii. A sharp decrease of Ca/ $\mathrm{Al}$ occurs in the upper sequence (Seg. iii), consistent with more fluvial inputs.

Heavy metal enrichments have been typically associated with a human impact [25], but they could also be associated with natural thresholds due to bedrock origins [28]-[29]. We considered that the high values found in the Marriaga Swamp profile (Fig. 6) are a combination between natural thresholds from basic bedrock weathering and specific anthropogenic effects associated with mining activities upstream the Atrato River that can incorporate mined sediments during floods into the Marriaga Swamp [30].

$\mathrm{Cu}, \mathrm{Ni}, \mathrm{Zn}, \mathrm{Co}$, and $\mathrm{Cr}$ concentrations were normalized with average Upper Continental Crust (UCC) concentrations [31]-[32] and compared to regional background data (Fig. 7) from stream sediments sampled by the Geological Survey of Colombia upstream the Marriaga Swamp in the Atrato River [33]. The purpose of this normalization was to determine if the heavy metal concentrations in the Marriaga Swamp showed extreme thresholds.

The normalization of heavy metals against the UCC shows that all concentrations are several times higher than the UCC values, which points to the possible anomalous enrichment of $\mathrm{Cu}, \mathrm{Ni}, \mathrm{Zn}, \mathrm{Co}$, and $\mathrm{Cr}$ in the swamp. The values for the regional background are also higher compared to the UCC and conservatively close to those found in the Marriaga Swamp sediments, except for Cr, which is higher for the regional records. Natural leaching could be one of the causes of the high values in the Marriaga Swamp sediments, which is also related to the high Chemical Index of Alteration (CIA) and the dilution effect of silica that promotes heavy metal dilutions [34]. 
If human activities were the most substantial reason for heavy metal enrichment in the Marriaga Swamp, the concentrations would be higher only in the upper sediments (Seg. ii) after 500 a, resulting from colonial mining [35]. However, the values in the profile (Fig. 7) demonstrate a constant presence along with the sequences. Since intense human presence or activities are not reported in the area before $500 \mathrm{a}$ in the late Holocene (corresponding to Seg. i and part of Seg. ii: $\sim 1130 \pm 70$ to $500 \mathrm{a}$ ), it is unlikely heavy metals are only a contribution of human sources.

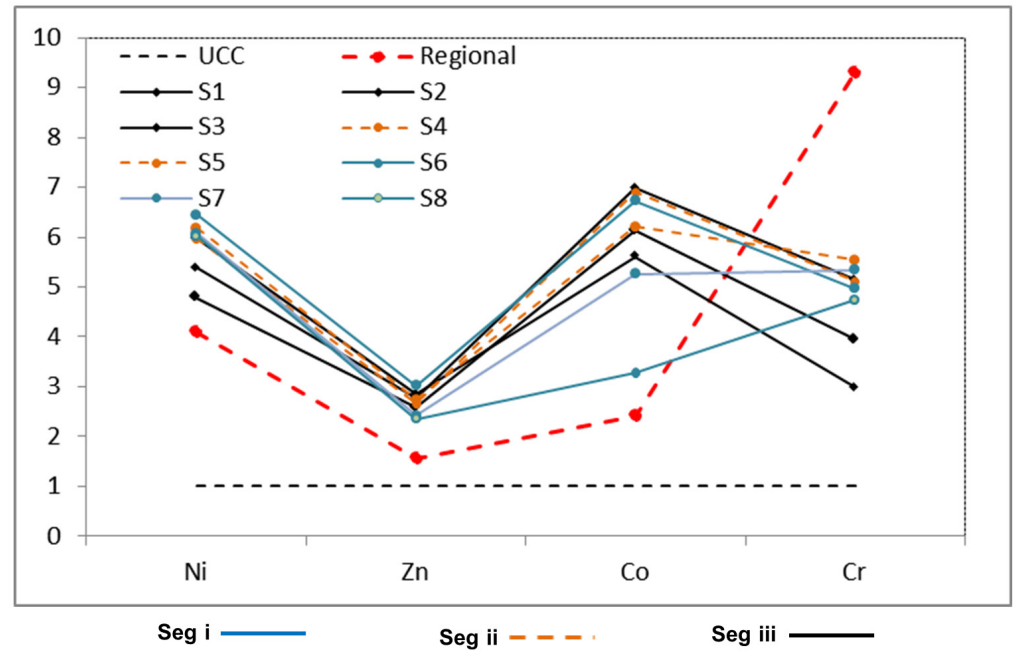

Fig. 7. $\mathrm{Ni}, \mathrm{Zn}, \mathrm{Co}, \mathrm{Cr}$, and regional background normalized against UCC.

Source: Own elaboration

\section{Chemical Index of Alteration (CIA)}

The CIA is used as a proxy of weathering grade and paleoclimatic signal to distinguish humid and arid conditions [36]-[38]. The cIA has been employed to examine the relationship between some major elements and assume the disintegration of feldspars and further formation of clay minerals during the weathering processes [39]. We used the cia to determine the production of detrital sediments and their contributions to sediment accumulation in the lacustrine setting of the Marriaga Swamp. The CIA is the molecular percentage of principal (oxides) elements (Equation 1):

$$
C I A=\frac{A l 2 O 3}{A l 2 O 3+C a O *+N a 2 O+K 2 O} X 100
$$

Where $\mathrm{Al}_{2} \mathrm{O}_{3}, \mathrm{Na}_{2} \mathrm{O}$, and $\mathrm{K}_{2} \mathrm{O}$ are the mole percentage and $\mathrm{CaO}^{*}$ is the calcium content of silicates.

An increase in CIA values is generally attributed to climatic fluctuations from cold to warm and humid [40]-[41]. For the Marriaga Swamp, the CIA is in a medium range for the lower sedimentary sequence $(220-162 \mathrm{~cm})$ and high over $162 \mathrm{~cm}$ to near-surface (Fig. 8). The CIA increases within the medium range from bottom to upper sequences, indicating climatic changes from $1,130 \pm 90$ a to present, from more arid and maybe colder conditions in late Holocene to humid and warmer conditions nowadays. 


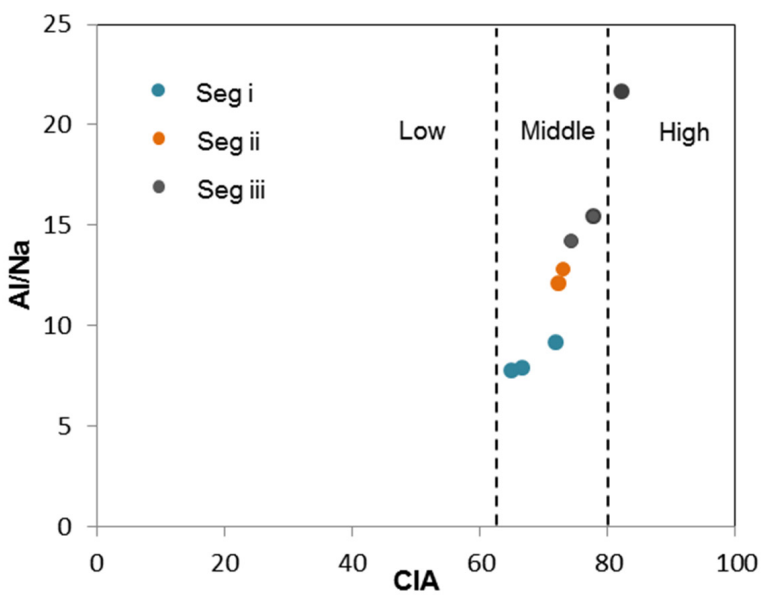

Fig. 8. Al/Na ratio versus CIA for the Marriaga Swamp sediments.

Source: Own elaboration

The CIA ranges hint at low weathering from 0 to 40 , moderate from 40 to 70 , and high from 70 to 100 [40]. The Marriaga Swamp cIa values range from 65 to 82, with an average of 72 , which means the Marriaga Swamp sediments are highly weathered.

\section{Statistical analysis}

We applied a Pearson correlation to identify the statistical significance association $(r>0.70 ; p$-value $>0.05$ ) between OC, depth, major elements, and trace elements (Table 2). The results can be clustered in three main groups: 1) OC has a positive correlation with $\mathrm{Na}$ and $\mathrm{Ba}$, concerning organic features and biological productivity, 2) $\mathrm{Si}, \mathrm{Fe}, \mathrm{Mg}$, $\mathrm{Na}, \mathrm{Ca}, \mathrm{K}, \mathrm{Ba}, \mathrm{Cl}$, and $\mathrm{Cu}$ are positively correlated with depth, concerning the interpretation of bedrock components, and 3) $\mathrm{Cr}, \mathrm{Zn}$, and $\mathrm{Co}$, related with heavy metal inputs.

A Principal Component Analysis (PCA) of the variables $\mathrm{OC}$, depth, major elements, and trace elements (Fig. 9) reveal that PC-1 explains $54 \%$ of the total variance and is positively linked to $\mathrm{Al}, \mathrm{OC}$, $\mathrm{Ba}, \mathrm{Na}, \mathrm{Mg}, \mathrm{Ca}, \mathrm{Si}, \mathrm{Cl}, \mathrm{K}, \mathrm{Ti}, \mathrm{Cl}$, and depth and negatively linked to $\mathrm{Fe}, \mathrm{Cu}, \mathrm{Zn}, \mathrm{Co}$, and S. PC-2 accounts for $24.1 \%$ of the total variance and is positively linked to $\mathrm{Mg}$ and $\mathrm{P}$ and negatively linked to $\mathrm{Cu}, \mathrm{Zn}, \mathrm{Co}, \mathrm{S}, \mathrm{Cr}, \mathrm{Ti}, \mathrm{K}, \mathrm{Cl}$, and $\mathrm{Si}$.

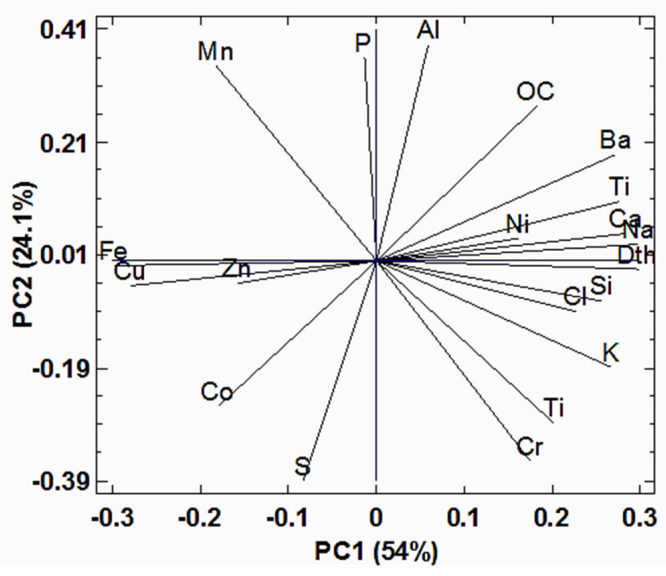

Fig. 9. Biplot of pc-1 versus PC-2 for OC, depth, major and trace elements in the Marriaga Swamp. Source: Own elaboration 


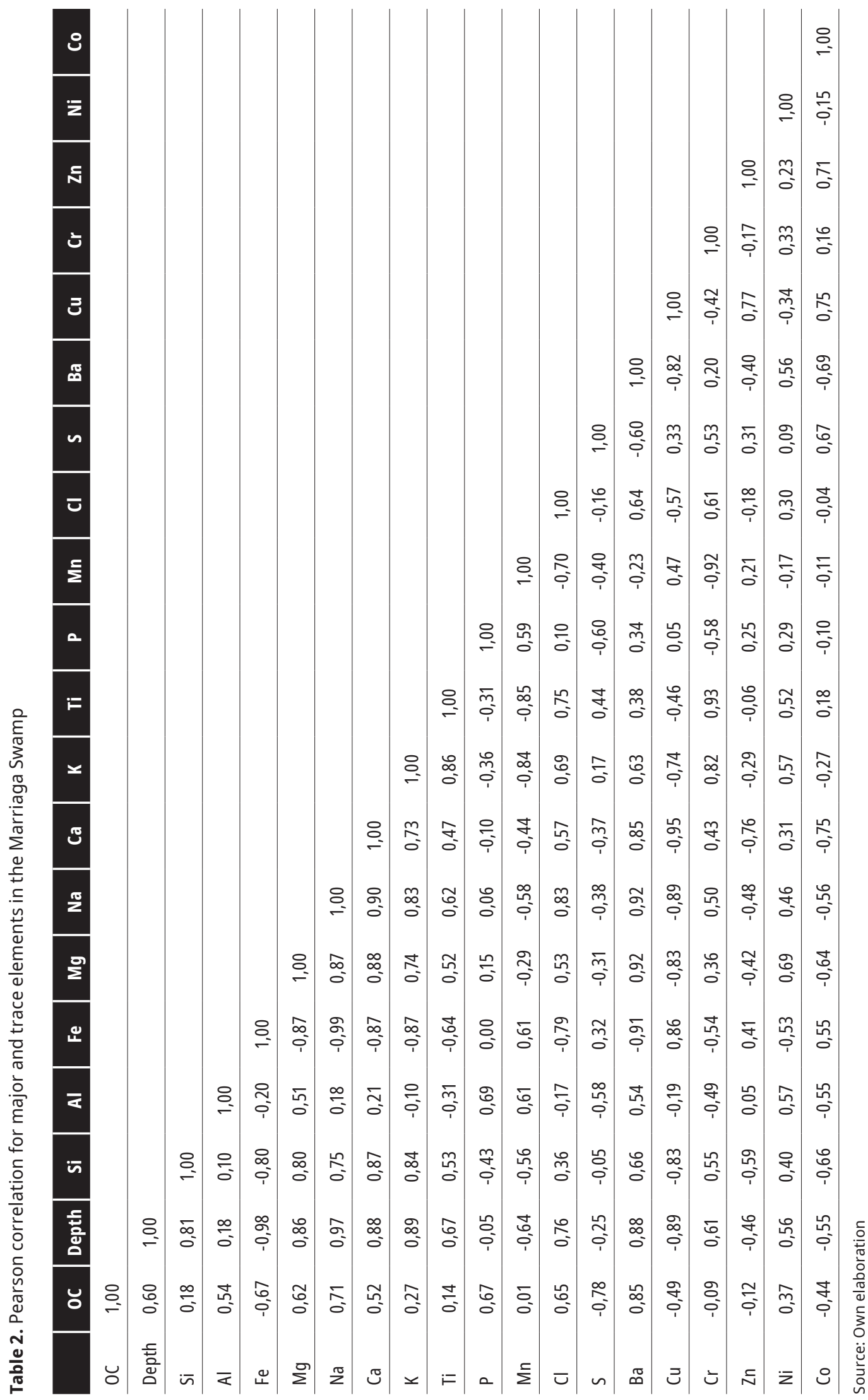


The positive values of PC-1 indicate more detrital and allochthonous components, whereas the negative values denote more anoxic conditions and heavy metal components, which also could justify the humid and dry alternations inside the Marriaga Swamp. Positive values of PC-2 may imply an endogenic precipitation process, supported by the $\mathrm{Mg}$ and $\mathrm{P}$, whereas negative values of PC-2 suggest heavy metal precipitation, combined with saline-brackish swamp regimes.

\section{Geochemical signatures in northwestern Colombia during the Late Holocene}

The Marriaga Swamp sedimentary sequence analyses contribute and complement the paleoenvironmental reconstructions for northwestern Colombia [42]-[43]. This research specifies the alternation of humid and dry conditions in the Atrato River delta setting in the last millennium. These climatic alternations are consistent with the migration of the ITCZ during the Holocene in the north of South America [44]-[46].

Based on geochemical proxies such as the oscillations of $\mathrm{Si}, \mathrm{Al}, \mathrm{K}$, and $\mathrm{Ti}$ (representing detrital inputs) and $\mathrm{Ba} / \mathrm{Al}$ and $\mathrm{Sr} / \mathrm{Al}$ ratios, we identify different authigenic lacustrine and allochthonous processes in the Marriaga Swamp. The lower sequence (Seg. iii), for instance, is characterized by the predominance of a dry (arid) phase, where the high OC represents the potential for lamination of fine sand (coarsest sediments of the sequence) [47]. Sediment reworking and carbonate precipitations also occur at the lower end of the sequence, as illustrated by the $\mathrm{Ca} / \mathrm{Al}$ ratio and the high concentrations of heavy metals ( $\mathrm{Cu}, \mathrm{Ni}, \mathrm{Co}, \mathrm{Zn}$, and $\mathrm{Cr}$ ).

On the other hand, Seg. ii represents a transition period between dry to moderately humid conditions. This part of the sedimentary sequence exhibits a light decrease in detrital inputs ( $\mathrm{Si}, \mathrm{Al}$, $\mathrm{K}, \mathrm{Ti}$, and $\mathrm{Fe}$ ) and a reduction of $\mathrm{OC}$ and carbonate production, represented by a low, $\mathrm{Ca} / \mathrm{Ti}$ ratio and the deposition of finer sediments (wide clay layer interbedded with some coarser lamination towards $90 \mathrm{~cm}$ deep).

The upper sequence (Seg. iii) is the clearest sedimentary section representing more humid conditions and fluvial influence, with a significant drop of detrital $\mathrm{Si}$, rise of $\mathrm{Al}$, and moderate presence of $\mathrm{Na}$ and $\mathrm{Ca}$. A rise in biological productivity is inferred by high $\mathrm{Fe}$ concentrations and $\mathrm{Mg} / \mathrm{Ca}$ ratios. However, the tidal influence is represented by high $\mathrm{Ba} / \mathrm{Al}$ ratios towards the lowest part of the sequence $(<25 \mathrm{~cm})$. Concentrations of heavy metals also prove an increase of $\mathrm{Cu}, \mathrm{Ni}$, and $\mathrm{Zn}$ for Seg. iii, possibly related to human activities such as mining, whereas the reduction of $\mathrm{Cr}$ and Co could be interpreted as the influence of intense weathering and dilution of natural sources for these two metals.

\section{Conclusions}

The sedimentary sequence and the geochemistry of the Marriaga Swamp expose significant environmental changes that occurred during the last $1130 \mathrm{a}$ in the Atrato River delta. Detrital contributions portray flooding events, generally associated with high concentrations of $\mathrm{Si}, \mathrm{Al}, \mathrm{K}, \mathrm{Ti}$, and Fe in sediments. In contrast, high concentrations of Ca reveal the possibility of sediments reworking during dry periods and level fluctuations in the Marriaga Swamp. Biological productivity manifests in the high contents of organic carbon and high carbonate precipitation $(\mathrm{Mg} / \mathrm{Ca})$. Higher $\mathrm{Ca} / \mathrm{Al}, \mathrm{Sr} / \mathrm{Al}$, and $\mathrm{Ba} / \mathrm{Al}$ ratios are also indicative of endogenic calcite precipitation. The presence of high concentrations of heavy metals $(\mathrm{Cu}, \mathrm{Zn}, \mathrm{Co}, \mathrm{Ni}$, and $\mathrm{Cr})$ along the entire sequence of the Marriaga Swamp sediments imply that their origin is likely a combination of natural bedrock sources and human impacts, especially towards the more recent deposits. High regional background concentrations for the same metals suggest natural enrichments of these heavy metals due to dilution processes in the sources that feed the swamp. The CIA is high along the sedimentary sequence, with a remarkable increase towards the surface, which points to a transition from arid to more humid conditions. The statistical correlations show three main clusters that distinguish among organic and biological productivity, bedrock source components, and heavy metal inputs. 


\section{Acknowledgments}

This study was supported by the Colombian Administrative Department of Science, Technology, and Innovation (Colciencias, Call 727/2015) as part of the first author's Ph.D. in Environmental Engineering at Universidad de Antioquia. We thank the GAIA research group of Universidad de Antioquia, the Köln University of Germany, the XRF Lab of the Materials Engineering Department, Universidad de Antioquia, the IRLS Freiburg University, the DRX Laboratory of the Universidad de Antioquia, and the Pascual Bravo Technological Institute in Medellín for facilitating sample preparation and laboratory essays. Special thanks to Dr. Frank Preusser for supporting, advising, and holding the IRSL dating of ARD sediments of the first author during her internship in 2018 at the Ludwig University of Freiburg; to Dr. Stephen Optiz from the University of Köln for performing laser grain size essays; to Dr. María Teresa Flórez from Universidad de Antioquia for her invaluable academic support. Sincere thanks to the communities of the Atrato Delta region that assisted the first author during field campaigns and project dissemination.

\section{References}

[1] S. Lojen and N. Williams, "Geochemical and mineralogical characterization of sediments from Lake Futalaufquen ( $42.8^{\circ} \mathrm{S}$, Andean Patagonia) to evaluate their potential as paleoclimatic proxies," Quat. Res., vol. 98, pp. 1-18, 2020. https://doi.org/10.1017/qua.2020.34

[2] A. K. M. Hasberg et al., "Modern sedimentation processes in Lake Towuti, Indonesia, revealed by the composition of surface sediments," Sedimentology, vol. 66, no. 2, pp. 675-698, 2019. https://doi.org/10.1111/ sed. 12503

[3] X. Zhang, D. E. Walling, X. He, and Y. Long, "Use of landslide-dammed lake deposits and pollen tracing techniques to investigate the erosional response of a small drainage basin in the Loess Plateau, China, to land use change during the late 16th century," Catena, vol. 79, no. 3, pp. 205-213, 2009. http://dx.doi. org/10.1177/0959683615574584

[4] I. Matthias and T. Giesecke, "Insights into pollen source area, transport and deposition from modern pollen accumulation rates in lake sediments," Quat. Sci. Rev., vol. 87, pp. 12-23, 2014. http://doi.org/10.1016/j.quascirev.2013.12.015

[5] H. Sakai, R. Fujii, M. Sugimoto, R. Setoguchi, and M. Paudel, "Two times lowering of lake water at around 48 and $38 \mathrm{ka}$, caused by possible earthquakes, recorded in the Paleo-Kathmandu lake, central Nepal Himalaya," Earth Planets Space, vol. 68, no. 1. pp. 1-10, 2016. https://doi.org/10.1007/s11368-019-02420-5

[6] A. E. Self et al., "The relative influences of climate and volcanic activity on Holocene lake development inferred from a mountain lake in central Kamchatka," Glob. Planet. Chang., vol. 134, pp. 67-81, 2015. https:// doi.org/10.1016/j.sedgeo.2006.04.006

[7] J. P. Corella et al., "Sediment dynamics in the subaquatic channel of the Rhone delta (Lake Geneva, France/ Switzerland)," Aquat. Sci., vol. 76, no. S1, pp. 73-87, 2014. https://doi.org/10.1007/s00027-013-0309-4

[8] F. Ocakoğlu et al., “A 2800-year multi-proxy sedimentary record of climate change from Lake Çubuk (Göynük, Bolu, NW Anatolia)," Holocene, vol. 26, no. 2, pp. 205221, 2016. https://doi.org/10.1177/0959683615596818

[9] M. L. Carrevedo et al., "A 700-year record of climate and environmental change from a high Andean lake: Laguna del Maule, central Chile $\left(36^{\circ} \mathrm{S}\right)$,' Holocene, vol. 25, no. 6, pp. 956-972, 2015. https://doi. org/10.1177/0959683615574584

[10] M. S. Tonello et al., "Geochemistry and mineralogy of southwestern Lake Superior sediments with an emphasis on phosphorus lability," J. Soils Sediments, vol. 20, no. 2, pp. 1060-1073, 2020. https://doi.org/10.1007/ s11368-019-02420-5

[11] N. Fagel, E. Thamó-bózsó, and B. Heim, "Mineralogical signatures of Lake Baikal sediments: Sources of sediment supplies through Late Quaternary," Sediment. Geol., vol. 194, no. 1-2, pp. 37-59, 2007. https:// doi.org/10.1016/j.sedgeo.2006.04.006

[12] S. Purnawan, I. Setiawan, and Z. A. Muchlisin, "Sediment grain-size distribution in the Lake Laut Tawar, Aceh Province, Indonesia," Aquac. Aquarium, Conserv. Legis. Int. J. Bioflux Soc., vol. 8, no. 3, pp. 404-410, 2015. http://www.bioflux.com.ro/aacl

[13] J. D. Correa, "Calidad del agua en humedales del plano de inundación del río Atrato," Rev. Cienc. Ambient. Sostenibilidad CAS, vol. 1, no. 1, pp. 93-109, 2014.

[14] A. F. Rúa Cardona, M. T. Flórez Molina, and J. P. Baena, "Variación espacial y temporal en los contenidos de mercurio, plomo, cromo y materia orgánica en sedimento del complejo de humedales de Ayapel, Córdoba, noroccidente colombiano," Rev. Fac. Ing., no. 69, pp. 244-255, 2013. 
[15] G. Bernal and J. Betancur, "Sedimentología de las lagunas costeras: Ciénaga Grande de Santa Marta y Ciénaga de Pajarales," Bol. Investig. Mar. Costeras, vol. 25, pp. 49-76, 1996. https://doi.org/10.25268/bimc.invemar.1996.25.0.370

[16] J. D. Restrepo and S. A. López, "Morphodynamics of the Pacific and Caribbean deltas of Colombia, South America," South Am. Earth Sci., vol. 25, no. 1, pp. 1-21, 2008. https://doi.org/10.1016/j.jsames.2007.09.002

[17] G. Poveda, "La hidroclimatología de Colombia: una síntesis desde la escala inter-decadal hasta la escala diurna," Rev. Acad. Colomb. Cienc. Exactas Fís. Nat., vol. 28, no. 107, pp. 201-222, 2004.

[18] Y. Thomas, M. Cesaraccio, C. García, and L. Ménanteau, "Contribución de la hidrografía histórica al estudio de la cinemática de los fondos marinos: evolución del golfo de Urabá, Colombia," Bolet. Cientif. $\mathrm{CIOH}$, vol. 25, pp. 110-119, 2007.

[19] G. Rodríguez and G. Zapata, "Características del plutonismo Mioceno Superior en el segmento norte de la Cordillera Occidental e implicaciones tectónicas en el modelo geológico del Noroccidente colombiano," Bolet. Cienc. Tierra, no. 31, pp. 5-22, 2012. https://revistas.unal.edu.co/index.php/rbct/article/view/31250

[20] E. Lugo, R. Rodríguez, and G. Domínguez, "Prospección Geológica y Geoquímica Regional en el Área de Mandé," Ingeominas, Bogotá, Colombia, Inf. Tecn., 2003.

[21] G. Bedoya et al., "Inventario, compilación, interpretación y evaluación integral de la información geológica, geofísica y geoquímica de lIIa cuenca Atrato y cuenca San Juan,” ANH, Bogotá, Colombia, Inf. Técn., 2007.

[22] H. Gonzalez, Investigación Integral del Andén Pacífico Colombiano. Tomo 1 Geología, Bogotá, Colombia: IGAC-Ingeominas, 2001.

[23] L. Betancurth, F. Preusser, D. Mueller, C. Rambeau, and J. Cañón. "First luminescence chronology of late Holocene deposits of the tropical Atrato Delta, Colombia," J. South Am. Earth Sci., vol. 104, p. 102813, 2020. https://doi.org/10.1016/j.jsames.2020.102813

[24] C. Martin-Puertas et al., "Geochemical processes in a Mediterranean Lake: a high-resolution study of the last 4,000 years in Zoñar Lake, southern Spain," J. Paleolimnol., vol. 46, no. 3, pp. 405-421, 2011. https://doi. org/10.1007/s10933-009-9373-0

[25] M. Carbonell Ventura, A. Navarro Flores, and Borrell Ruscalleda, "Heavy metals contamination and seawater intrusion in the northeastern of delta river Foix (Barcelona)," Bolet. Geolog. y Min., pp. 1-24, 2014.
[26] R. M. Joeckel and B. A. Clement, "Surface features of the Salt Basin of Lancaster County, Nebraska," Catena, vol. 34, no. 3-4, pp. 243-275, 1999. https://doi. org/10.1016/S0341-8162(98)00114-3

[27] M. Haberzettl et al., "Lateglacial and Holocene wet-dry cycles in southern Patagonia: chronology, sedimentology and geochemistry of a lacustrine record from Laguna Potrok Aike, Argentina," Holocene, vol. 17, no. 3, pp. 297-310, 2007. https://doi. org/10.1177/0959683607076437

[28] J. Ridgway, N. Breward, W. J. Langston, R. Lister, J. G. Rees, and S. M. Rowlatt, "Distinguishing between natural and anthropogenic sources of metals entering the Irish Sea," Appl. Geochemistry, vol. 18, no. 2, pp. 283-309, 2003. https://doi.org/10.1016/S08832927(02)00126-9

[29] P. Negrel, "Multi-element Chemistry of Loire Estuary Sediments: Anthropogenic vs. Natural Sources," Estuar. Coast. Shelf Sci., vol. 44, no. 4, pp. 395-410, 1997. https://doi.org/10.1006/ecss.1996.0139

[30] Y. Palacios-Torres, K. Caballero-Gallardo, and J. Olivero-Verbel, "Mercury pollution by gold mining in a global biodiversity hotspot, the Choco biogeographic region," Chemosphere, vol. 193, pp. 421-430, 2018. https://doi.org/10.1016/j.chemosphere.2017.10.160

[31] S. M. Mclennan, "Relationships between the trace elements composition of sedimentary rocks and upper continental crust," Geochem. Geophy. Geosy., vol. 2, no. 4, pp. 1-24, 2001. https://doi. org/10.1029/2000GC000109

[32] K. H. Wedepohl, "The composition of the continental crust," Geochim. Cosmochim. Acta, vol. 59, no. 7, pp. 1217-1232, 1995. https://doi.org/10.1016/00167037(95)00038-2

[33] E. Parra, "Potencial de recursos del subsuelo en la cordillera occidental zona Norte, fase 0," Ingeominas, Bogotá, Colombia, Inf. Tecn., 2006.

[34] M. A. H. Bhuiyan, M. J. J. Rahman, S. B. Dampare, and S. Suzuki, "Provenance, tectonics and source weathering of modern fluvial sediments of the Brahmaputra-Jamuna River, Bangladesh: Inference from geochemistry," J. Geochemical Explor., vol. 111, no. 3, pp. 113-137, 2011. https://doi.org/10.1016/j.gexplo.2011.06.008

[35] L. Bénat-Tachot, "Santa María la Antigua del Darién: chronique d'une infortune locale," e-Spania, no. 2006, pp. 12-32, 2015. https://doi.org/10.4000/e-spania. 25105

[36] D. Meunier, A. Caner, L. Hubert, F. El Albani, and A. Pret, "The weathering intensity scale (wIS): an al- 
ternative approach of the chemical index of alteration (CIA)," Am. J. Sci., vol. 313, no. 2, pp. 113-143, 2013. https://doi.org/10.2475/02.2013.03

[37] G. E. Qian, X. U. E. Z. George, Y. E. Liming, and X.

U. Dong, "Distribution Patterns of Major and Trace Elements and Provenance of Surface Sediments on the Continental Shelf off Western Guangdong Province and Northeastern Hainan Island," J. Ocean Univ. China, vol. 18, no. 4, pp. 1-10, 2019. https://doi. org/10.1007/s11802-019-3738-4

[38] K. Goldberg and M. Humayun, "The applicability of the Chemical Index of Alteration as a paleoclimatic indicator: An example from the Permian of the Paraná Basin, Brazil," Palaeogeogr. Palaeoclimatol. Palaeoecol., vol. 293, no. 1-2, pp. 175-183, 2010. https://doi. org/10.1016/j.palaeo.2010.05.015

[39] G. M. Nesbitt and H. W. Young, "Early Proterozoic climates and plate motions inferred from major element chemistry of lutites," Nature, vol. 299, no. 5885, pp. 715-717, 1982. https://doi.org/10.1038/299715a0

[40] S. O. Oni and A. S. Olatunji, "Depositional environments signatures, maturity and source weathering of Niger Delta sediments from an oil well in southeastern Delta State, Nigeria," Eurasian J. Soil Sci., vol. 6, no. 3, pp. 259-274, 2017. https://doi.org/10.18393/ejss.297245

[41] L. Harnois, "The cIw index: A new chemical index of weathering," Sediment. Geol., vol. 55, no. 3-4, pp. 319-322, 1988. https://doi.org/10.1016/00370738(88)90137-6
[42] C. Vélez- Agudelo and N. Aguirre-Ramírez, "Influencia del río Atrato en el golfo de Urabá durante el holoceno tardío, mar caribe colombiano," Bol. Investig. Mar. Costeras, vol. 45, no. 1, pp. 73-97, 2016. https:// doi.org/10.25268/bimc.invemar.2016.45.1.631

[43] A. Rua, G. Liebezeit, R. Molina, and J. Palacio, "Unmixing Progradational Sediments in a Southwestern Caribbean Gulf through Late Holocene: Backwash of Low-Level Atmospheric Jets," J. Coast. Res., vol. 32, no. 2, pp. 397-408, 2015. https://doi.org/10.2112/JCOASTRES-D-14-00216.1

[44] R. J. Smith and F. E. Mayle, "Impact of mid to late Holocene precipitation changes on vegetation across lowland tropical South America: a paleo-data synthesis," Quat. Res., vol. 89, no. 1, pp. 1-22, 2017. https:// doi.org/10.1017/qua.2017.89

[45] S. Sachs, J. P. Sachse, D. Smittenberg, R. H. Zhang, Z. Battisti, D. S., and Golubic, "Southward movement of the Pacific intertropical convergence zone AD 14001850," Nat. Geosci., vol. 2, no. 7, pp. 519-525, 2009. https://doi.org/10.1038/ngeo554

[46] A. Jerardino, "Late Holocene Neoglacial episodes in southern South America and southern Africa: comparison," Holocene, vol. 5, no. 3, pp. 361-368, 1995. https://doi.org/10.1177/095968369500500313

[47] N. Tribovillard, T. J. Algeo, T. Lyons, and A. Riboulleau, "Trace metals as paleoredox and paleoproductivity proxies: an update," Chem. Geol., vol 232, no. 1-2, pp. 12-32, 2006. https://doi.org/10.1016/j.chemgeo.2006.02.012 